\title{
Modernization of Arab Linguistic Sciences in Modern Age
}

\author{
Salahuddin Mohd. Shamsuddin ${ }^{1}$, Siti Sara Binti Hj. Ahmad ${ }^{2}$ \\ 1 Prof. Dr.: Arab-Islamic Literature, Islamic University Sultan Sharif Ali, Brunei Darussalam \\ E-Mail: shamsuddinsalahuddin@gmail.com /Tel: +67-8364851 \\ 2 Dr. Dean: Faculty of Arabic Language, Islamic University Sultan Sharif Ali, Brunei Darussalam. \\ E-mail: sara.ahmad@unissa.edu.bn /Tel: +6738858379
}

\begin{abstract}
Arabic was the language of philosophy, logic, Islamic sciences and rhetorical linguistic sciences. It was used in the writing of all sciences generally and became the language of world culture. Although the other languages of the Islamic world had a little share, but all peoples of Islamic countries; Arabs and non-Arabs, Muslims and non-Muslims attributed to that movement appreciated. Hence, Arab sciences flourished in their bright ages.

Arabic language was a cultural container of the ancient Greek and Latin intellectual heritage. As the ancient Greek and Latin sciences and literatures were translated into Arabic in the bright ages of Islam. Arab language was a strong bond for them, as a common human heritage for the centuries to save it from being lost, as Muslims used it to develop their sciences and arts, as Muslims in the East used the Western sciences and literatures in the modern age, because they are not Eastern or Western, but the common efforts of all humanity.

Arabic language opened for the dictionaries and other tongues of cross-fertilization, civil friction and simulation. Arabic had become the language of sciences: mathematics, astronomy, engineering, logic, philosophy, mysticism, agriculture, industry and economics by the continuous efforts of scientists in their scientific research, invention, experimentation, knowledge collection and classification in various fields, where orientalists recognized the Arab leadership. That scientific and literary civilization moved to Europe through Italy, Andalusia, Crusades and the Ottoman Caliphate. Europeans learned Arabic language, literature and sciences in the centers of Toledo, Fez and cities of Maghreb.
\end{abstract}

Keywords: Arab Sciences; Greek Logic; Islamic Philosophy; Heretical Books; Modernization of Arab Rhetorical Linguistic Sciences in the contemporary age. 


\section{Introduction: (Arabic Language)}

Anyone who looks at the history of Arabic language will find himself puzzled and impressed by the rich linguistic heritage that has amazed the world in its long history with the great generosity and scientific and literary production for the mankind as the hole, because Arabic is the language of Holy Qur'an and Sunnah.

We see that Arabic in the pre-Islamic era was the language of poetry and artistic creativity, represented by the seven pendants and the poems of the poets and the sources of the Arab poetry such as the reference books written by al-Mufaddal and al-Asmayi and the mass of Arab poetries, that are referenced by all of the researchers, writers and critics in every era and region. Arabic language was characterized by the eloquent words, the eloquent meanings, splendor of expression and good quality of style in the systems of speech.

When Islam spread in the Arabian Peninsula, Asia and Europe, Arabic was a tool for the communication and understanding with the other peoples.

In fact, the translation of Greek books into Arabic was a powerful factor that pushed the ancient Arab criticism in the Abbasid period forward, because it had been transferred some manifestations into Arabic literature and criticism that had an impact on the mental movement of literary criticism. Then the assets and theories were developed and the logic used in the argument and dialogue, the books in criticism were authored, that were full of the scientific and mental methods established by the Arab critics. The effect of this had also been evident in the development of Arab criticism, especially the Greek influence (the logic and philosophy). The first impact was on the scholastic speakers who saw their urgent need for the philosophy to defense the accusation to Holy Qur'an. Muslim scholars became able by studying Aristotelian logic and philosophy, especially his book: (Poetry) and (Rhetoric) to bring out the Arab criticism from the pure Arabian atmosphere, to the wide horizons, where many of the mental and logical reasons and measurements were taken from Greek features, and the impact of this simulation in the fourth century AH clearly can be seen on Qudāma bin Ja far in his book: (Criticism and poetry) and (criticism and prose) attributed to him by mistake, because the real author of this book is (Ibn Wahb) from Andalusia, as well as, appeared on the book: (Miracle of Qur'an) authored by al-Romani, and this impact appeared also on the critics of the fifth century AH, such as al-Bāqallānī in his book: (Miracle of Qur'an) and Ibn Sin̄̄n al-Khafājīi in his book: (Mystery of Eloquence). [1] 
One of the main factors for the development of the old Arab criticism in Abbasid Era was the Qur'an, as it had a direct and indirect impact. The direct impact, was because of the efforts were done by the scientists who were exposed to the style of Qur'an and its graphic aspects of the statement, trying to compare between the Arab poetry and the likeness of graphic and characteristics Arabic statement in general, and using the means used by critics of the poetry, even some of the Qur'anic studies in the third century AH used some graphic terms, were not common until that time in the poetic criticism such as the book (interpretation of the problem in the study of Qur'an) written by Ibn Qutayba ${ }^{1}$, and rules of the criticism mixed up with the Qur'anic studies, so the scientists of Qur'anic studies used the magnificent miracle terms of the rhetoric science for detection of the miracle method in Qur'an, to find its likeness, hence impact of the Qur'an was in the curricula of the critics, pushing them to demonstrate the images of the miracle, so they piled on proving its miracle, as al-Bāqallānī wrote in his book: (The statement of Qur'an). [2]

Then the standards of literary criticism mixed with the Qur'anic studies, and the scientists of Miracles used the science of (Good Style) and its chapters in the disclosure of the exquisite style of the Qur'an to reach the miracle. Hence, there was an impact of Qur' an on the methods of critics, which prompted them to demonstrate the miraculous reasons, so they tried to prove the miracle, and its best statement, even better than the Arab poetry, and they held for that comparisons, as Abd al-Q̄̄hir al-Jurjōn̄ī did in his book: "Evidences of Miracle" and al-Bāqallān̄i in his book: "Interpretation of Qur'anic Miracle". As for the indirect impact came through the beauty of Qur'anic eloquence to the tastes of critics, including the style, which was the beautiful drafting and images of wonderful similes and metaphors, making scientists to quote its drafting and similes for every generation. Then the Qur'anic examples became at the forefront of evidences in the books of literary criticism and rhetorical science.

\section{Role of Arab Scholars in the development of Arab Sciences in their golden era}

\section{A. Arabic Language and Philosophy}

The Arabs had a special passion for their language, which was characterized by the abundance of vocabulary, abundance in the images of expression and the derivation by its nature, to take its place among the languages of the world, even if we compare between Arabic and Latin with its weight and lack of flexibility or Arabic and Persian with its dilation we find that Arabic is characterized by the short verbal images of abstract meanings. This is a great benefit in the practice of sciences. 
We can express in this language the most subtle differences between the meanings ... Arabic language has the beauty of the statement and the power of significance, so it was imperative to prepare the reasons for many researches when it became a language of Science to Syriac and Persians. It is said that the people of Basra have given the measurement a great importance in the provisions related to the matters of language, as the people in Baghdad did the later, while the grammarians in Kufa were authorized in many matters that were different to the measurement. This is the cause that the grammarians in Basra were called: "People of logic". Then a great debate held about the issue that the rhetoric is found in the word or in the sense? Then the debate held about the language. Is it an innate compromise or from the human status, then the philosophical opinion has prevailed gradually that it is a term of human status. [3]

\section{B. Islamic Philosophy}

There is a question: Why many Muslim philosophers use the word "wisdom" as the synonyms with the word "philosophy" which has entered Arab Islamic thought as an Arabic word for the Greek word "philosophy". Many of the famous Sufis used the title: "Hakim" for their senior figures such as al-Hakim al-Tirmizī. The title: "philosopher / philosophers" was called only on those who work in the field of philosophy within the context of Greek philosophy.

The philosophy began in Islamic civilization as an intellectual current in the early beginnings of the Islamic state, beginning with the science of speech. It reached its peak in the 9th century when Muslims became acquainted with the ancient Greek philosophy, which led to the emergence of the first generation of Muslim philosophers who differed from theologians. The science of speech was based primarily on the legal texts of the Qur'an and Sunnah and the logical methods of language to build a protest method faced by those who try to challenge the facts of Islam, while the Muslim philosophers who adopted the philosophy of Greece, their first reference was the perception of Aristotle or Plato, which was considered by them compatible with the texts and spirit of Islam. In their attempts they used logic to analyze what they saw as constant cosmic laws arising from the will of God, they initially made the initial attempts to reconcile some of the gap that existed mainly in the perception of the nature of the Creator between the Islamic concept of God and the Greek philosophical concept of the first principle or the first mind. After the integration of philosophy into the religion, Islamic philosophy developed from the stage of studying issues that can only be proved by the texts transferred and worship to the stage of studying 
the issues that are limited to proof of mental evidence, but the common point through this historical extension was the knowledge of God and the proof of the Creator. This philosophical current reached to an important corner through Ibn Rushd, by his adherence to the principle of free thought and arbitration of the mind on the basis of observation and experience.

The first one of the Arab philosophers emerge was Kindī, who was called the first teacher among the Arabs, and then was Fōrabī who adopted a lot of the Aristotelian thought in the issues of effective mind, the oldness of the world and the concept of natural language. Farabi founded an intellectual school, where the most important figures were: Amirī, Sijistānī and Tawhidī. AlGhāzalī was the first to establish reconciliation between the logic and Islamic science when he explained that the methods of Greek logic can be neutral and separated from Greek metaphysical perceptions. Al-Ghōzalī expanded his explanation of logic and used it in the doctrine of the fundamentals of fiqh, but in return he launched a violent attack on the philosophical visions of the Muslim philosophers in the book: "The Flaming of the Philosophers".

Fōrabī is the most important person who has been able to communicate and explain the science of logic in Arabic through the book: "The letters". The book of letters authored by Fārabī occupies a special importance among his works. The book is considered as a research in the first philosophy, in addition to the discussion of linguists and scientists of scholastic speech on many of the problems that were mainly related to the relationship between the language and logic, and word and Meaning. Fōrabī tried to explain how the knowledge is made by the sense, starting from the experience, then the remembering and then the idea, by this way we find the emergence of practical and theoretical sciences. He explained the idea and the origin of sciences. Fōrabī explains the stages of the emergence of language saying that at first the idea is born in the human, then signal comes, then the sounds, and the development of sounds arise the letters and words. Thus the words and vocabularies are formed: The first sense and then its image in the mind and then the word, which is used for the expression. At a later stage, the words and expressions consist of combining words and vocabularies to reflect not only the things but the relationships that bind them. Fōrabī uses a literal method to define the relationship between the word and the meaning and determines the primacy of meaning before the word. In the same context, he decides that the system of words (language) is an attempt to simulate the system of ideas (in the mind). The system of ideas in the mind is not but an attempt to simulate the system of nature outside through the 
relationships among the tangible physical objects. It can be decided by the result of the analysis determined by Fōrabī that there are two systems: a system of the words trying to simulate the arrangement of the relationship among the meanings in the self, and another independent system of concepts and meanings trying to simulate the arrangement of sensory objects in the physical exterior. Hence there is a need for two sciences:

First. Science of the language or linguistics, which means the sight of the language and its relations with their meanings and significance.

Second. Science of the logic, which means the order of the concepts and methods of correct conclusion of the issues of intuitions by the mind, i.e. rules of correct thinking. Then, the stage of collecting the language and saving it from the intruder and the stranger words that come in the order of Fārabī, and then codification of the language by establishing the rules that control the method of writing and pronunciation (Emergence of Arabic Grammar). [4]

\section{Greek Logic and Arab-Islamic Sciences}

Arabs were interested in the logic of Aristotle since Ibn al-Muqaffa'. At first they started to translate it, then began to explain it and write its abstract in many books, thus they chose this logic for the arbitration and adopted it in the development of their sciences, as we found its example in the science of jurisprudence and its rules in Islam, where the scholars speak about the borders and definitions, universal and partial, general and particular, common and proper, we find other words of the measurement similarly and prominently in the science of Arabic language and grammar, as we see grammarians, since (al-Halīl b. 'Aḥmad al-Farāhīdī) are expanding to speak on the measurement, as they are expanding in their statements about the four reasons: material, imaginary, efficacy and extremity, but the grammarians and scholars and other Arab scientists were guided to know clearly that the Aristotelian measurement sports analogy, it starts from the general form and asks for its partial vocabulary. Its truth was noted in the mathematical sciences, but in the natural and human sciences we must move to its opposite: from the individuals and vocabularies to the general form to be well-founded measure. This has had a dramatic impact on the Arabic sciences, because the extrapolation and note are two basic originals in this measurement, then it was included the experience in the natural sciences, thus the Arab sciences became enable to promote the great renaissance in each area, a renaissance had been prepared for the prosperity of Medicine and Pharmacy, thanks to the many experiments were conducted by pharmacists and doctors, as well as in chemistry, optics, astronomy and huge laboratories. 
In the opinion of Šawqī Dayf "perhaps the most important literary research work among the Arabs, which shows the impact of Aristotelian logic clearly, is the book written by Ibn Wahb: (al-Burhān fì Wujūh al-Bayān fí Nuşūş al-Qur'ān) means: (proof of statement styles in the texts of the Qur'ān) which is published with a wrong title: (Criticism of the prose) and is attributed to Qudāmah b. Ğa far. We see that the author of this book wrote a chapter of the measure in which he talks about the limits of definitions, descriptions and statements and also the use of these species in Arabic sciences, he is affected by Aristotelian logic in all these species with what is added by research scholars, speakers and most Islamic philosophers in their articles and ideas. The religious curricula had been developed for dealing with religious sciences which is explained in the chapters of "Science of the religious rules": "'Ilm al-'Uşūl” dealing with the texts of the Qur' ān and "Sunnah": (spoken words by Prophet Muhammad) the consensus and measurement. Similarly, rules of Arabic language and its grammar also were developed, as it is shown in the book: (al-Haşā iş) the characteristics" which is written by Ibn Ğinnī. [5]

In this way, Arabs used Aristotelian logic in their literary researches with some hidden attempts to take care of the particles and vocabulary, the completeness of extrapolation and the validity of devising. They expanded their notes to a wide range that are called in their literary research the experiments in the scientific research, but they remained maintaining the Aristotelian logic using a lot of rules and values.

They differ from medieval Western scholars in their worship of Aristotle's logic. They reflected by the induction: The transition from the general to the particular, making it the transition from the partial to the general, and they stopped the effectiveness of Aristotle's logic, as they introduced the experimentation and the observation in proving the truth without the need for limits, statements and values. [6]

The Aristotelian writings, in particular (Organon), which had already been translated into Arabic by Ibn Rushd, Ibn Sina, Farabi, Kindi and the others in the old ages, and Abdul Rahman Badawi in modern times, are known as the means or instrument in Arabic. This Greek word was used as the title of Aristotle's collection of essays in the sense of the means of thinking and judging its validity or corruption by the logical means set out by Aristotle in his books. [7]

\section{Bright Ages of Arabic and Arab Sciences}

As we have seen that Arabic language has known its cultural peak with the Abbasid state, which stretched in a vast area, especially with the era of the three caliphs: Abu Jaafar al-Mansour and al- 
Mamoon and Harun al-Rashīd. Arabic had a great importance as the language of translation for the thought of foreign languages such as Greek, Persian, Indian and Romanian, as it was seen in the House of Wisdom founded by the Caliph al-Ma'mun to transfer the cultural heritage of Greek into Arabic. In this period the knowledge and science spread and Arabic literature flourished as Arabic language opened on the dictionaries, other languages of the cross-fertilization and civil friction and simulation.

Arabic language became the language of sciences: Mathematics, astronomy, geometry, logic, philosophy, mysticism, agriculture, industry and economics. It flourished by the efforts of scientists in their scientific research, invention, experimentation, knowledge collection and classification in various fields, where the Orientalists recognized the Arab leadership as the German scientist Ziegried Honke wrote a book: "Arab sun shining on the West". That scientific and literary civilization moved to Europe through Italy, Andalusia, Crusades and the Ottoman Caliphate. Europeans learned Arabic language, literature and sciences in the centers of Toledo, Fez and cities of Maghreb.

However, Muslims deviated from the teachings of Holy Quran and Sunnah and became victims of humiliation and after they were the masters. God gave them a lot of invaders and enemies, assuring them of various types of psychological and social suffering such as the tyranny, enslavement, colonization, murder, slaughter and starvation. Islamic world has reached the abyss of decay and backwardness, which has been the result of the development progress that Europeans and Americans have already achieved, because of their interest in the science and the encouragement of scientists. The result of this backwardness was the decline of the status of Arabic language in the Arab and Islamic world and the questioning of people in their expressive and deliberative capacities; for they no longer considered Arabic the language of civilization, science and technology, but the language of the past, the Bedouin, the ancestors and their dead heritage. Thus, the minds of the Arab intellectuals were preoccupied with the endless discussions on the subject of classical language, the issue of originality and modernity, and how to deal with the West since the Renaissance until today. [8] 


\section{Lack of the creativity and scientific production in Arabic in the modern age}

There are several reasons that prevent Arabic language and put it away from the artistic creativity, and prevent them from using their expressive capabilities to scientific production. These reasons can be limited to the following:

A. Lack of a good understanding of the teachings of Quran and the principles of Islam, which calls on Muslims to pay attention to the science, encourage the scientists and link the scientific research with ethics and the benefit of people.

B. Colonialism, which took several visible and invisible faces stand against the progress of the Islamic peoples through the aggression, intimidation, threats and starvation.

C. Most of the Arab and Islamic countries are undemocratic, are fighting their peoples and standing against their scientists by looking for the starvation, exile, arrest and execution. Such as: Egypt, Syria, Iraq and the others. They also neglect the scientific research and do not give it the least attention and do not allocate the necessary financial, material and human resources to achieve the technological and scientific development.

D. The effectiveness of other Arab and Islamic peoples are disabled and their social, economic and cultural affairs are in a state of crisis and it is difficult to find the suitable treatment for them. It has a great influence on Arab and Islamic institutions, institutes and universities that are no longer able to keep abreast of the tremendous scientific developments and the many technological inventions of recent decades, especially in the field of digital knowledge, communications and the economy. They have internal and external factors and causes.

E. These reasons made Arabic unable to compete with the other foreign languages, including English, which became the language of science and technology. The reason for this is the failure of Arabs and Muslims to create, invent and discover, and rely on the West to import theories and transfer technology and scientific knowledge that required the knowledge of these languages to teach them, dealing with them in the markets, management and educational centers.

The result of this phenomenon was that "many Arab researchers and Muslim scholars neglected the use of Arabic language, because it is no longer the language of science, and most of the inventions and achievements of knowledge, art and literature are written in by the name of 
their owners and in foreign terms, it is difficult to translate or Arabicize them or transform it into a generative or derivative term in Arabic.

The language has a dialectical relation to the thought, so if there is an intellectual creativity developed the language is the case of this thought, and if the thought is lower, the language is also in the manner of degenerate, backward and unable to reply the process.

Lack of awareness and loss of confidence in Arab capabilities and lack of pride prevents them from expressing in Arabic and resort to the other languages in the preparation of research, articles and books to catch up with the global cultural requirements.

The media, the economy and the bitter reality of the globalization era contributes to the marginalization of Arabic language and the strengthening of foreign languages. Globalization has pushed many national languages of weak peoples, promoting English as the language of civilization, contemporary life and global communication. Negatively on the Arab man and his language, which is no longer able to keep up immediately with the contemporary developments of scientific and technical knowledge after the development of digital means and artificial satellites because of the lack of political and educational strategies to develop the Arabic language and improve it and make it the language of science and technology, teaching and administrative and economic transactions.

It is clear from the foregoing that there are some internal and external factors that are the reasons for the loss of the ability to the artistic and scientific creativity and cultural production in Arabic. [9]

\section{Evolution of Arabic language in the development of human sciences}

Any language in order to become a science language must have all levels of sound, morphology and stylistics easy to read and rich by the meaning and the derivation. This is what that Arabic language had in its old time, and in all those sciences that Arabs excelled in them. The development of the language is not limited to the language only, but there are many Arab Muslim scholars who have contributed to the development of human sciences in Arabic.

Thus, we find that the Arabic language is not narrow, it can keep pace with the results of science, but is suitable for scientific and technical teaching because of the breadth of its lexical capacity compared to the foreign languages. A positive advantage of Arabic language is that it 
benefits from the phenomenon of expression, dissolution, derivation, Arabization and seclusion, all of these help it to open up and benefit from all the languages of the world. [10]

\section{Linguistic Sciences in Arabic and Modern Linguistics}

Linguistic study is a new type of language study that adopts modern methods and sources that are not limited to this or that language. So there is nothing wrong with adding this subject to the language sciences in Arabic. In this subject, many books, such as: (Arabic language meaning and structure) by Dr. Tammam Hassan, (Linguistic Thinking in Arab Civilization), by Dr. Abdul Salam Al-Masaddi, and (Principles of Linguistics) by Dr. Ahmad Mohamed Qadoor, which suggests that the proposed Arabic language lesson can be true unless it is preceded by a careful examination of the achievements of Arab scholars in every field studied, and a conscious understanding of the approaches and objectives of the proposed linguistic lesson.

Linguistic studies in the West since the nineteenth century have seen expansion and matureness. This development has brought about a scientific renaissance that continues to extend today. These studies that became known "Linguistics" were not in their quest only for the scientific study of linguistic phenomena, but also this communication and its impact has led to the emergence of some new branches of linguistics, but the linguistic area was the basis of these branches such as linguistic, social linguistic, geographical linguistic, and so on. The 18th century saw the emergence of Philology, which was wrongly translated into Arabic, but did not exceed the limits of the preliminary work required to study the language. However, Ferdinand Dossier (1913) made linguistics clear in terms of the competence, which encompassed all sectors of the language, such as sounds, grammar, lexicon and semantics, and in terms of the curricula that matured like the historical, comparative and descriptive approach. As the landmarks of this new science began to loom in the modern linguistic lesson among the Arabs (the Arab scholars) were divided between those who believed in this science and its greatness and those who did not respect it and did not count on what it did in the West, so that they would appreciate it. As for those who considered it great, they have made it the pole in every study, therefore, what the ancient Arabic studies had done in the language and its curricula became so small in their eyes.

The right is that "the linguistics should be a factor of modernization not a factor of destruction, and to be useful to our lesson in terms of addition and enrichment, not to be for the purposes of mutilation and cancellation. For example, in the field of language, it is useful to update 
the curriculum of the linguistic lesson, to clear this lesson from the data that is outside the field of language, and to acquire new linguistic sciences on the guidance of modern perspectives such as the science of sounds and semantics and lexicography, which is not known in our lesson as a methodological or epistemological framework, with the abundance of efforts and the capacity of data. As well as, science of Arabic language can be benefited by many of the results of Comparative linguistic studies, and philological studies to know the place of Arabic among its sisters through the history, and to be benefited by the results of the lesson of Etymology to know the sources of the true knowledge of the Arabized words, and many more."[11] Especially by the semantics, because Arabs were the first in the science of the voices and the creation of dictionaries. It is known that the semantics are the sectors of the modern linguistic study. The field of this science is to study the linguistic meaning at the levels of vocabulary and structures, although its prevailing concept is to put the science of semantics limited in the study of vocabulary and what is related to its issues. Indeed, the growth of modern semantics and the complexity of its methodological approaches -as Abd al-Salam al-Masaddi says- has made it the pole of rotation in every linguistic research, inseparable from the theory of cognition and the philosophy of meaning. [12] Hence, the semantics became broader than any other science that studies the vocabulary, dictionary and terminology, [13] but this statement does not mean -in any way- the abolition of any kind of the linguistic knowledge to Arabs such as Arabic grammar, morphology, linguistics, semantics and lexicon under the pretext of renewal or keeping pace with the times. It should also be noted that being benefited by any of the modern approaches should not lead to ignore the specificity of classical Arabic and its surrounding historical, cultural and national conditions. [14]

\section{Validity of Arabic to be the language of science and technology}

We do not need this question: Can Arabic be the tool of science and technology? Arabic is good for being a container of science and technology, as it was in its bright ages, it was the language of science, arts and literature, because of its beautiful words, its rhetorical statement and the rigor of its composition. So it was accepted by the other peoples to learn, study and research. As it was the preferred language of many peoples and races such as Persia, Andalusia and Islamic countries of Maghreb. Many of the books and works have moved to Europe in Arabic, then their contents have been transferred to them through the translation, as many Western scholars and orientalists did such as Ibn Rushd, Ibn Sina, Al-Zuhri, Al-Khwarizmi, Ibn Al-Nafìs and the others. 
The language - any language - is linked to the level of thought, because the thought cannot be found without the language at the same time the language cannot be found without the thought. As it is said by John D. LA Croix, that the thought is the body of language and the language is the dress of thought, as it is also stated by Maurice Merleau-Ponty, which means that the languages are rich not by their vocabulary only but also by their profusion of ideas. If the nation is advanced in terms of the science, technology, arts and literature, inevitably, the language in its turn also will be advanced as long as it contains the thought and it is a tool for the communication and information.

In fact, the progress of language is always linked to the progress of the nation's thinking, creativity and production. When we demand the teaching of science in Arabic, this does not mean the lack of openness to other languages and self-containment. Arabic language is able to accept differences, dialogue and discussion since ancient times, when it was in the contact to the neighboring peoples. Language is the cradle of the civilization and culture for every nation, and it must be the language of modernity, progress and present life in keeping with the current developments and requirements of the times. [15]

\section{Conclusion}

At the end we say that the movement of orientalists as a scientific and objective method is well known, but we do not agree with those deviant views that are not on the right path, for, those who violated the Orientalists objective approach to scientific research, scientific integrity and betrayed biased in their studies, they produced to prove the European centrality and they wrote under the influence of racial discrimination between peoples in the East and West.

We cannot support those who say that the rhetorical sciences had not only filled of the error and negligence, but also they took the wrong direction from the beginning. Therefore, it was impossible to produce some valuable thing in the literary taste and the disclosure of its real beauty. These sciences had been developed mostly by the men from Persian speakers who wrote these without their share in the intuitive Arabic, tracing Aristotle in the poetry, oratory and logic and they drunk from which was translated from Greek Philosophy and what was created by this philosophy and built in Urban Islamic Philosophy, theology, doctrine, assets and the various branches of purely intellectual debate in emerging period of the Islamic culture, which was under the early development. 
The science of rhetoric in Arabic, especially semantics is closer to the scientific logic, which seems to be a talk more than to be called rhetorical science. Therefore it is rare to find in this type of science, which is named by them master science of the rhetorical sciences (jokingly). They use what they have in this science to sharp the artistic sense or to polish the literary taste or to point out the real secrets in Arabic rhetoric, but it is not true, as it makes the taste of the scholars and their mental ability more corrupt and distort.

The science of speech, even it consists on some correct graphic means, as metaphor, analogy and comparability, and euphemism, had a very limited look to these means and had barely understood as only a rigid templates excelled in restriction of the formal manifestations and terminology.

We never support this opinion, because we believe that they count those efforts a loss of time or downplay its importance, whether those efforts have been made by Persians or Arabs, it is fact that Arabic sciences flourished in the Abbasid period after the outcome of valuable books written by those who set the basis for the creed of Islam or its specific system, they succeeded in defending against the heretics, apostates and the infidels from the followers of Mazdaism, Manichaeism and Sabaean. Their defense was very fruitful, even its example almost never seen in the history of religious sects. There is no doubt that Islam has dominated the large yards after a great victory, replacing itself on the old beliefs, obsolete religions, and completely crushed the effects of old thinking, as many of the Jews, Christians, and followers of Mazdaism and Manichaeism, Sabaean spread among Muslims, who had brought these foreign elements, ideas and doctrines caused the emergence of Islamic world. Then, these scientists and theologians tried their best to persuade their opponents, and were able with their outstanding talent in the controversy and debate to beat them in the end.

The argument that these sciences are written mostly by the people from Persian speakers whose share was less in the intuitive Arabic, here, we smell populist tendencies, but we cannot say that the contemporary critic in saying this is affected by the populism between Persians and Arabs, which does not exist in modern age, but the correct view is that this opinion is impressed by the idea of the race, which is brought by Helypolite Martine Taine, which means the inherent instinct in the nation, as each nation descended from innate racial-specific characteristics shared by the predecessor and successor, without any exception. It seems it was taken from Renan, who -lived between 1823-1892- illustrated in his book; "The history of the Semitic languages" that the Semitic 
nations do not have the philosophy and the excellent literary works, but Aryan nations are distinguished with their philosophy, right social laws, the high arts and literature.

This theory has no longer any support today, whether the race is only people who lived in one territory had been living together, which formed during the course of living, similar habits and knowledge. In ancient time the races changed, when peoples were attacked by each other and by the armies of the territory of other provinces, therefore, the idea of the original race is completely wrong. [16]

In fact, the translation of the books into Arabic was a strong factor that prompted the old Arab criticism forward in the Abbasid era, because it had moved by its literary and critical translation, which had an impact on the mental movement of the criticism, as the rules and theories had been composed, the logic used in the debate and dialogue, and the critical books had been written, had the scientific methods and mentality that was founded by Arab critics. This was reflected also in the development of Arabic criticism, particularly impact of the Greek logic and philosophy and its first impact was on Muslim scholastic theologians who saw the urgent need of philosophy to defend the attacks against Qur'ān and succeeded through the study of the logic and philosophy, especially (the poetry) and (the oratory) written by Aristotle, so that they became able to bring out the Arab criticism from the original Arab environment to a wide horizons, which had many of the reasons, mental and logical measurements of Greek features, that Greek impact appeared in the fourth century (AH) and clearly in the book: (Critique of the poetry) written by Qudāma bin Ğa far, in the book: (Critique of the prose) written by Ibn Wahb, it also appeared in the book of al-Rummānī: (Remarks in the miracles of Qur'ān) and appeared also in the books of critics lived in the fifth century (AH) as in the book: (Miracles of Qur'ān) written by al-Bāqallānī and in (Secret of the Eloquence) written by Ibn Sinān al- Hifāăḡi.

As for the indirect impact came through the beauty of Qur'anic eloquence to the tastes of critics, including the style had the beautiful drafting and images of wonderful similes and metaphors, making scientists to quote its drafting, and similes for every generation, then the Qur'ānic examples became at the forefront of evidence in the books of literary criticism and rhetorical science.

Moreover, the schools of doctrines and theories represent always the spirit of their age, classical school represents the spirit of its era, and the romantic school after the death of classicism, 
every age has its logic, old literary criticism or Arab literary rhetoric represents the old Arab era and its logic, as well the modern criticism has its approach. Not to deny that the literary criticism in its ancient time, and modern age had flourished after its connection to the Western literatures as Arabic literature flourished after its relevance to the Eastern literatures. So the literary research works should be free of the traps of populist and nationalist arrogance and bigotry.

As well as, we never accept to say that the rhetorical books spoiled Arabic tastes instead of breeding and development. We say that we must not doubt in the faith of the senior rhetorical scholars and critics who added to the Arabic and Islamic libraries some new valuable additions by their enormous efforts, rather than to recognize the genius in this regard, how can we blame them and put them in the dock, because of they used Aristotelian logic? Yes ... They used it to be able to respond to the logic of other nations by their own mental logic, as we see what al-Giazâlī has been done in his books against philosophers, while that age was not able to understand any method except Aristotelian logic. As well as, we never accept that Islam will be accused of inability to hear or accept any element of civil and social life removed from its land all the seed of mental culture, as Renan said and his student Jean-Paul Guiltier spoke with the same meaning, confirming that (Islamic faith is less likely than any other religion to the initiatives of the human mind). There is no more wrong than this. We have seen the mind enters the field of faith, as it entered the jurisprudence in Islam. Indeed, the mind in the latter eras is superior to configure the measurement and inference resemblance, and in the first era to configure the evidence argument.

As well as we are not with those who say that rhetorical efforts were misleading or did not produce any valuable thing or a vain effort. We are sure that they do not feel the seriousness of these sentences that are very serious adverse, which can make a Muslim scholar away from the valuable books of senior scholars, as he never study the neglected enormous efforts that had not lost its effectiveness until now. It deals with issues of faith in the unseen world, which still exist, the polytheists or atheists, materialists and existentialists in the modern era - until now - could not find any solution towards convincing only to deny the existence of God, as we see Nietzsche, Walter, Sartre, Caspar, Gabriel Marcel and the others. Then, these sentences are very serious, for it is destroying the building of the originality of old heretical Islamic thought, but it interferes with the desired goal of Muslims who are doing their best to revive the greatness of scientific and cultural heritage of genius Muslim thinkers who have contributed to the establishment of a very strong Islamic culture from its base. 
It is true that Islamic world has been contained on the traditional and liberals, conservatives and innovators, but these opposing elements are essential to every community in every age of historical eras of human societies. Who says today that the rhetorical efforts are futile, we must not forget the definition of the literature in the modern era, when the Western scholars have said that literature is: (the human race, age and environment). Therefore, critic must evaluate rhetorical efforts that were done in their ages, by Arabic Rhetorical scientists at that time. How we can say that those efforts futile shoot to a desired goal, to enrich the Arabic and Islamic arts and sciences were created by those fruitful efforts and flourished, even those periods of the time began to be known (because of those sciences) by the name of its brighten time. Every era has its own characteristics and advantage and each kind of the doctrines expresses the psychological state of a certain specific era.

We appreciate these geniuses and scientists recognizing their merit, whether they are Isolationists or scholars of rhetoric and Islamic theology who have contributed to laying the cornerstone of Islamic culture, especially Kindi, Farabi, Ibn Sina, Ghazali, Ibn Rushd of the philosophers of Islam, Qudamah bin Jaafar, Ibn Wahb, Jahiz, al-Askari, Baqallani who have contributed to build the basis of Islamic Philosophy, which got victory over their opponents by their mental logic and methodology and maintained on the doctrine of their religion and school of thought, as they have their great attitudes and their clear fingerprints of an entity to protect ArabIslamic heritage. They defend its faith and its message with all sincerity and enthusiasm and honesty. Their faith is reflected in every word that comes out of their tongues and pens. 


\section{References}

[1] Al-Salām. Muhammad Zağlūl. (No date). Impact of the Qur'an on the development of the Arabic criticism, Cairo, House of the knowledge. P. 101

[2] 'Afyfĩ. Raf 'at Maḥmūd. (1990). Aspects of Arab literary criticism, Cairo, House of Al-Muhammadiya Printing.

[3] See: "Contributions of linguists in the development of Arab Sciences" (December 2012) (Internet).

[4] Ibid, the same article.

[5] Dayf. Šawqī. (1972). Literary Research. Cairo: House of the knowledge. Seventh edition. p.81-83

[6] Mandour. Mohammed. (No date). Literature and its arts. Cairo: Renaissance of Egypt for printing and publishing. P. 6

[7]Article: Hamdawi. Jamil (December, 2006). Teaching of linguistic sciences in Arabic. (Internet).

[8] Ibid. (Same Article).

[9] Ibid. (Same Article).

[10] Qaddur. Ahmed Mohamed. (1996). Principles of linguistics. Damascus: House of the contemporary thought. R: P. 5-6

[11] Al-Masaddi. Abd al-Salam. (No date). Dictionary of linguistics. P. 21-22

[12] Qaddur. Ahmed Mohamed. (1996). Principles of linguistics. Damascus: House of the contemporary thought. P. 279

[13] Ibid., P. 6

[14] Article: Hamdawi. Jamil (December, 2006). Arabic language and science teaching. (Internet).

[15] Revolution against the rhetoric, lecture delivered at the American University, Magazine: al-Hilal, Fourth issue of the sixth year, p. 266

[16] Ḍayf. Šawqīi. (1972). Literary Research. Cairo: Dār al-Ma'ārif. Seventh edition. pp. 88-89 